\title{
A composição de comunidades micorrízicas das orquídeas Zygopetalum mackayi e $Z$. pedicellatum é relevante para sua coexistência?
}

\author{
Andressa H. Regina*, Lais S. Sisti, Juliana L. S. Mayer, Samantha Koehler
}

\section{Resumo}

Para testar a hipótese de que as orquídeas que apresentam maior distribuição geográfica estabelecem associações generalistas com simbiontes fúngicos e que orquídeas com distribuição mais restrita apresentam associações mais específicas, estudamos duas espécies de orquídeas irmãs e simpátridas, Zygopetalum mackayi Hook. e Z. pedicellatum (Sw.) Garay, que apresentam distribuição ampla e restrita, respectivamente. Identificamos para as duas orquídeas fungos endofíticos não micorrízicos pertencentes ao filo Ascomycota e micorrízicos (Basidiomycota). Apenas a comunidade de fungos endofíticos não-micorrízicos é distinta entre as duas espécies de orquídeas. Possivelmente o método de cultivo de fungos testado não é eficiente para o cultivo de fungos micorrízicos, uma vez que só conseguimos identificá-los através do sequenciamento direto da raíz das orquídeas.

\section{Palavras-chave:}

Ascomycota, fungos endofíticos, Tulasnellaceae

\section{Introdução}

O presente projeto de pesquisa teve como objetivo analisar a comunidade micorrízica entre duas espécies de orquídeas irmãs e simpátridas, Zygopetalum mackayi Hook. e Z. pedicellatum (Sw.) Garay. Nós testamos a hipótese de que espécies de orquídeas que apresentam maior distribuição geográfica estabelecem associações generalistas com simbiontes fúngicos, enquanto que orquídeas com distribuição mais restrita apresentam associações mais específicas (Swarts \& Dixon 2009). Sabendo que $Z$. mackayi apresenta uma distribuição geográfica muito mais ampla e heterogênea do que $Z$. pedicellatum (FLORA DO BRASIL 2017), nossa previsão para as espécies em estudo é que $Z$. mackayi apresente maior diversidade fúngica do que $Z$. pedicellatum.

\section{Resultados e Discussão}

Realizamos o cultivo de 70 fungos micorrízicos, sendo 27 resultantes das raízes de $Z$. mackayi e 43 de $Z$. pedicellatum. Em seguida foi feita a extração de DNA e amplificação da região ITS1-2 dos fungos cultivados e de seis amostras de raízes, sendo três de cada espécie. Os testes de amplificação da região ITS1-2 com os iniciadores específicos para fungos micorrízicos orquidóides falharam nas amostras dos fungos isolados. Entretanto, amplicamos com sucesso 12 fungos de $Z$. mackayi e $22 Z$. pedicellatum utilizando iniciadores mais genéricos para região ITS1-2. Já a amplificação utilizando iniciadores específicos para fungos micorrízicos orquidóides foi bem sucedida para todas as seis amostras de raízes. A comparação das sequências obtidas com o banco de dados GenBank através do algoritmo BLAST indicou que todos os fungos endofíticos cultivados pertencem ao filo Ascomycota, não sendo, portanto fungos micorrízicos. A comunidade dos fungos Ascomycota entre as duas espécies de orquídeas é distinta, com apenas espécies de Xylariaceae em comum (Tabela 1). Já para as amostras de raízes, identificamos fungos micorrízicos pertencentes a família Tulasnellaceae (Basiodiomycota), não havendo diferenças significativas entre as orquídeas.
Tabela 1. Fungos Ascomycota identificados para as orquídeas Zygopetalum mackayi Hook. e Z. pedicellatum (Sw.) Garay a partir de sequências de DNA da região ITS 1-2 através do algoritmo BLAST.

\begin{tabular}{ll}
\hline Amostra & Fungo identificado \\
\hline Z. mackayi & Colletotrichum gloeosporioides \\
& Chaetomium subspirale \\
& Nemania abortive \\
& Nigrospora oryzae \\
& Xylariaceae sp. \\
& \\
Z. pedicellatum & Ilyonectria sp. \\
& Hypoxylon investiens \\
& Pestalotiopsis oxyanthi \\
& Pestalotiopsis microspora \\
& Pezicula rhizophila \\
& Pezicula rhizophila \\
& Podospora curvicolla \\
& Xylaria berteri \\
& Xylariaceae sp. \\
\hline
\end{tabular}

\section{Conclusões}

Não há variação nas as espécies de fungos endofíticos micorrízicos entre as duas espécies de orquídeas, mas fungos endofíticos não micorrízicos são muito diversos. 0 método de cultivo de fungos empregado é ineficiente para o cultivo de fungos micorrízicos, uma vez que só conseguimos identificá-los através do sequenciamento direto da raíz das orquídeas.

\section{Agradecimentos}

G. Mendes, N. Polizelli, T. Campacci pela ajuda no campo e/ou laboratório. Programa Institucional de Bolsas de Iniciação Científica (PIBIC/Unicamp). Fundação de Amparo à Pesquisa do Estado de São Paulo (FAPESP 2014/04426-5).

Flora do Brasil 2020 em construção. Jardim Botânico do Rio de Janeiro.

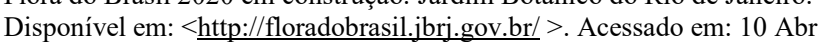
2017.

Swarts, N. D. e Dixon, K. W. Annals of Botany 2009, 104, 543. 